\title{
The Nexus of Human Development Index, Economic and Population Growth On Environmental Degradation In Aceh Province, Indonesia
}

\author{
T. ZULHAM ${ }^{1, *}$, TAUFIQ C. DAWOOD ${ }^{1}$, TALBANI FARLIAN ${ }^{1}$, JUMADIL SAPUTRA $^{2, *}$, \\ ROLLIS JULIANSYAH ${ }^{3}$, FAJRI HADI ${ }^{3}$ \\ ${ }^{1}$ Department of Economics \\ Faculty of Economics and Business \\ Universitas Syiah Kuala \\ Kopelma Darussalam, Syiah Kuala, 23111 Banda Aceh \\ INDONESIA \\ ${ }^{2}$ Department of Economics \\ Faculty of Business, Economics and Social Development \\ Universiti Malaysia Terengganu \\ 21030 Kuala Nerus, Terengganu \\ MALAYSIA \\ ${ }^{3}$ Department of Economics \\ Faculty of Economics \\ Universitas Teuku Umar \\ Ujong Tanoh Darat, Meureubo, 23681 Aceh Barat \\ INDONESIA
}

\begin{abstract}
Environmental degradation is a primary indicator in reducing sustainability and causing many of the challenges faced by humankind, such as climate change, water scarcity, inequality, and hunger. One way to resolve the sustainable issue (environmental degradation) is to promote sustainable development through a commitment to social progress, environmental balance, and economic growth. In conjunction with the present issue, this study aims to analyse the nexus of human development index, economic and population growth on environmental degradation in South Aceh District, Aceh Province, Indonesia. This quantitative study uses secondary data that involved three main variables: environmental degradation, economic growth, and population growth. This study data were collected from the Central Bureau of Statistics, Aceh, Indonesia and related Regional Government Agency for 20 years started 1997 to 2017. This study found that the human development index and population growth positively and significantly affect environmental degradation. Also, economic growth has no significant impact on environmental degradation. In conclusion, this study identifies that when the human development index low and population growth high, it would increase environmental degradation. Surprisingly, whereas economic growth does not significantly contribute to environmental degradation, this study can provide an overview of the nexus of human development index, economic and population growth on environmental degradation and its impact on society.
\end{abstract}

Key-Words: - Environmental degradation, human development index, economic and population growth

Received: September 12, 2020. Revised: March 9, 2021. Accepted: April 3, 2021. Published: April 14, 2021.

\section{Introduction}

Environmental degradation is reducing sustainability and causing many of the challenges faced by humankind, such as climate change, water scarcity, inequality, and hunger and a primary indicator in measuring the sustainable development goal. For many people in developing countries, economic growth is a challenge [1]. One way to achieve the conditions for developing an economy is to create and develop economic factors such as industry, agriculture, trade, and others [2]-[4]. For achieving sustainable development, enough capital and experts are needed, which aims to plan and look 
the government seriousness [5]. [6]-[9] writes in his book that long-term economic growth is significantly affected by increased investment, human capital, technological expertise, and industrial plants and equipment are all examples. [1]. The magnitude of capital flows, like Indonesia's, provides an opportunity to obtain funding for economic growth.

In the form of degradation, declining environmental sustainability affects livestock, deforestation, poor agricultural management, internal displacement and climate change in desertification, drought, and floods [10], [11]. It is also undeniable that with many investment, it is certainly opening up for developing the infrastructure such as roads, dams and factories to support the economic activities. So, at a certain point, if this situation out of control, it will cause negative externalities in the form of environmental degradation. Also, developing economic regions (central economic regions) will become a magnet for the population around and outside the area to try to be part of these developments.

Environmental degradation is influenced by economic activities and demographic events such as urbanisation, population age and population [5], [12]. According to Environmental degradation or environmental damage can reduce the level of economic development. It can reduce natural resources' productivity and cause various problems, from health problems to degrading life comfort. The recent increase in population has increased demand for basic needs, which is increasingly causing more significant environmental damage [13], [14]. Environmental degradation can also be influenced by per capita income that affects economic growth [15]-[17]. Population growth and migration into one place can affect the balance of people's distribution and affect the changing climate, availability of land, food, and environmental degradation [15].

The relationship between environmental change and the potential humanitarian crises in their studies have focused on geography and refugees and changes in the environment and population. They stated a close relationship between environmental change and population distribution, and population growth [18], [19]. Environmental degradation that has arisen recently varies from poor air quality to rising sea levels. It is inseparable from reducing forest area that causes prone to flooding and drought throughout the year. Some time ago, as [20] revealed in his research, a flood is a global problem that is often the case in Asia.

Floods themselves are caused by excessive rainfall, high tides and an inevitable extreme climate change. It exacerbated by human activities that damage the environment. It is in line with the research that says that climate change can be caused and accelerated by the pace of human activity; therefore, special management is needed to deal with it. Meanwhile, [21]-[24] revealed that protecting the environment is necessary and teaching disaster management to the community. The risk of natural disasters must address as a development problem and not just humanitarian assistance. Environmental degradation has become a severe problem in various regencies/cities, not least in areas close to the centre of environmental studies. South Aceh has the highest level of environmental damage [25]. The high increase in environmental degradation continues to occur, as data presented by the Central Statistics Agency (BPS) of Aceh Province stated that the environmental damage is getting bigger each year. [26]; [27]. People who are not prosperous tend to be affected by their livelihoods due to their dependence on natural resources.

The development has many sub-levels in achieving the expected economic growth, which is also interrelated with the Human Development Index (HDI). Good human development can produce innovation in developing efficient and effective performance technologies in development [28]. This condition experiences many challenges in managing environmental sustainability [29]. A causal relationship between economic growth, human development and sustainable resources and in carrying out good human development requires a balance of the environment, peace and humanitarian conscience. Therefore, there is a link between HDI and environmental degradation. The following is data of environmental degradation throughout the year and HDI figures in Aceh Selatan District, Aceh Province.

\section{Literature Review}

Development is often disregarding environmental sustainability. It happens a lot, especially in various developing countries, even in developed countries. It is like gambling when the balance of nature is no longer enough to eradicate and cope with pollution. The damage that occurs is greater than the ecosystem's availability. It will accelerate the occurrence of natural disasters and environmental degradation getting bigger. Environmental degradation is a process of exploiting nature, such as forest encroachment, conversion of land functions, drainage of peatlands and the use of fossil energy, and others. [30] and [31] revealed that unequal migration of people to a 
place and increasing population could affect the quality of the environment itself and resources in many developing countries.

Maintaining environmental sustainability from increasing environmental degradation is very important in achieving long-term human well-being. Excessive population pressure in some geographical regions can pose severe ecological hazards, including soil erosion, desertification, reduced supply of fuelwood, deforestation, and degradation of freshwater sources. Often the relationship between population pressure and other environmental stress types is growth in the relative and absolute numbers of people living in poverty [32]. [32] increasing world population without accompanied by policies that minimise environmental impacts can affect the welfare and sustainability of life [33]. On the other hand, economic growth is an economic condition in a country that has improved for the better condition, which is stated in a certain period. Economic growth is defined as a process of increasing the economic production capacity realised in the form of an increase in national income and improvement of the standard of living.

Economic growth is an indication of economic development's success, and economic growth has a significant relationship to the environment. Changes in environmental quality can lead to disasters and environmental balance. It caused by economic development by expecting high economic growth and being influenced by politics and other activities. [34] ; [35], increasing the density of economic integration across national borders can reduce poverty and reduce income inequality.[36] stated that poverty does not only talk about the absence of what is needed in achieving prosperity, such as clothing, food, and shelter, but also education, health, and others.

The poor residents are the resident who has an average per capita expenditure per month below the Poverty Line. Meanwhile, to measure the poverty line can be done through: The Food Poverty Line (FPL) is the value of minimum food expenditure equal to 2,100 kilocalories per capita per day. Poverty Line Non-Food (NFPL) is the minimum requirement for others' housing, clothing, education, health, and basic needs (BPS, 2018). The increase in population can affect the integrity of the ecosystem and imbalance. Increasing the number of populations that causes the density of space in an area and affects the environmental quality will affect health, air quality, and environmental degradation [37].
On the other hand, according to [38], said that economic growth could be influenced by education both formally and non-formally. The overall human development approach can participate directly in the starting point of development in the sustainable management of inherited resources. [35], [39] detailing the HDI formed by 3 (three) basic dimensions: Longevity and healthy living, knowledge, and a decent standard of living. The knowledge that can increase human development's capacity is a deciding factor in the impact of climate change that ends in a disaster.

\section{Method}

This study uses 1997-2017 time-series data from the Central Statistics Agency and the related Regional Government Agency. The estimation tool or model that is used is multiple linear regression (Ordinary Linear Square). It aims to see the cause of the degradation of the environment in Aceh Selatan district. Using the OLS analysis tool, this study also limits the environment's degradation as the dependent as measured by the number of occurrences of flooding or drought year. Flood and drought events in this research are indicators of environmental degradation because of the frequent occurrence of floods and drought in Indonesia, Aceh and Aceh Selatan District. The Independent variable is economic growth, as measured by the growth of gross value added or the GDP rate (Gross Domestic Product). HDI variable is the builder's men's investment value, and the poor can be seen from the number of poor people in its annual period.

This study's model is a multiple-linear regression model that environmental degradation influenced by economic growth, the index of human development and population growth or mathematically can be written: [40], [41].

$$
E D=a+\beta_{1} G R D P_{t}+\beta_{2} H D I_{t}+\beta_{3} P O G_{t}+\varepsilon_{t}
$$

Whereas ED is environmental degradation, GRDP is economic growth, HDI is the Human Development Index, and POG is population growth. $\beta 1, \beta 2, \beta 3$ is estimation coefficient, $\varepsilon t$ is the Error term.

\subsection{Hypothesis}

Based on the background and problem formulation developed above, the proposed hypotheses are the human development index, economic and population growth have a significant effect on environment degradation. 


\section{Results and Discussion}

\subsection{Results}

By applying the time-series regression analysis, the result of the model fit in this study, as seen in Table 1 below:

Table 1. The result of Model Fit

\begin{tabular}{llc}
\multicolumn{1}{c}{ Model } & \multicolumn{2}{c}{ Statistic } \\
\hline R & \multicolumn{2}{c}{$0.980^{\mathrm{a}}$} \\
R Square & \multicolumn{2}{c}{0.961} \\
Adjusted R Square & \multicolumn{2}{c}{0.921} \\
Std. Error of the Estimate & \multicolumn{2}{c}{0.05554} \\
\hline \multicolumn{2}{c}{ Square } & 0.961 \\
& Change & 24.379 \\
Change Statistics & F Change & 3 \\
& df1 & 3 \\
& df2 & 0.013 \\
\hline
\end{tabular}

Table 1 displays the result of model fit testing. We found that the value of coefficient determination $\mathrm{R}-\mathrm{Square}$ is 0.961 . It means that economic growth, human development index, and population growth can explain its environmental degradation relationship as much as 96.1 per cent. There are 3.9 per cent explained by other variables which have no included in this study. Further, the value of adjusted R-Square is 0.921 . In other words, when we added one or two variable in the model, it will increase the R-Square value as many as 92.1 per cent. Next, we present the result of hypotheses testing. It displays in Table 2 below:

Table 2. The result of hypotheses testing

\begin{tabular}{|c|c|c|c|c|c|}
\hline & \multicolumn{2}{|c|}{$\begin{array}{l}\text { Unstandardised } \\
\text { Coefficients }\end{array}$} & \multirow{2}{*}{$\begin{array}{c}\text { Standardised } \\
\text { Coefficients } \\
\text { Beta }\end{array}$} & \multirow[b]{2}{*}{$\mathrm{t}$} & \multirow[b]{2}{*}{ Sig. } \\
\hline & B & $\begin{array}{l}\text { Std. } \\
\text { Error }\end{array}$ & & & \\
\hline (Constant) & $\begin{array}{c}- \\
32.357\end{array}$ & 6.022 & & $\begin{array}{c}- \\
5.373\end{array}$ & 0.013 \\
\hline $\begin{array}{l}\text { Economic } \\
\text { Growth }\end{array}$ & -0.102 & 0.235 & -0.063 & $\begin{array}{c}- \\
0.435\end{array}$ & 0.693 \\
\hline Human & & & & & \\
\hline $\begin{array}{l}\text { Development } \\
\text { Index }\end{array}$ & 8.899 & 1.390 & 0.931 & 6.400 & 0.008 \\
\hline $\begin{array}{l}\text { Population } \\
\text { Growth }\end{array}$ & 0.428 & 0.123 & 0.406 & 3.482 & 0.04 \\
\hline
\end{tabular}

Dependent variable: Environmental Degradation
Table 2 above illustrates the result of hypotheses testing by applying time-series regression. Before conducting the hypotheses testing, we have run the normality, linearity, homoscedasticity and autocorrelation. By referring to the table above, we found that economic growth has no significant effect on environmental degradation. Further, the Human Development Index's coefficient regression is 8.899 , and the standard deviation is 1.390 , and the $\mathrm{t}$-stat is 6.400 , with a significant value is less than 1 per cent. It means that, by assuming there are no changes in the human development index, then environmental degradation will decrease as much as 8.899 per cent. Also, the coefficient regression for population growth is 0.428 , and the standard deviation is 0.123 , and the t-stat is 3.482 , with a significant value is less than 1 per cent. It means that, by assuming there are no changes in the human development index, then environmental degradation will decrease as much as 42.8 per cent.

\subsection{Discussion}

This study's result is that economic growth has a negative and not significant effect on environmental degradation; however, economic growth has not yet had a comprehensive impact on environmental degradation. In other words, the negative coefficient obtained indicates that the better the economic growth, the less environmental degradation. It suggests that economic development in Aceh Selatan is not necessary and has an impact on environmental degradation. In this case, in line with research by [42] says that environmentally friendly economic development can have a positive impact on environmental sustainability in the long term. In contrast, in developing countries, there is a negative correlation between economic growth and environmental sustainability. Due to the use of energy in the creation of development, it is often the defy environmental values in many developing countries [43]. How to move markets in development is a significant problem that policymakers must solve today. Essential in creating a growing economy and a healthy environment [4]. Policies in managing a flexible environment can improve leading technology in handling environmental problems caused by development [5].

The estimation results also show that human development in this context is focused on the HDI. The poor population's percentage has a positive and significant relationship to environmental degradation in Aceh Selatan District. In line with the Ministry of Human Resource Development research in 2018 [31], [36] said that poor population and human development could influence behaviour 
change and show the possibility of unfavourable directions in environmental condition. Partially the human development process is the most powerful in influencing environmental degradation. The same thing also expressed by [44] that economically disadvantaged people tend to be uncontrolled in exploiting nature such as forest encroachment and mangroves on the coast because they do not have land capital and are forced to use the land. It can damage the environment. However, this has a relatively low percentage; moreover, high Population growth can affect sustainability in environmental monitoring and the high industry operation in producing goods and services because of high market demand due to the population growth.

\section{Conclusions}

In conclusions, this study has identified that when the human development index low and population growth high, it would increase environmental degradation. Surprisingly, whereas economic growth does not significantly contribute to environmental degradation, this study can provide an overview of the nexus of human development index, economic and population growth on environmental degradation and its impact on society.

\section{Acknowledgements}

We would like to thank Universiti Malaysia Terengganu for supporting this research publication and one form of research collaboration with the Universitas Teuku Umar and Universitas Syiah Kuala.

\section{References}

[1] S. Muhamad, N. Fatimah, C. Sulaiman, and J. Saputra, "The Role of Human Capital and Innovation Capacity on Economic Growth in," J. Ekon. Malaysia, vol. 52, no. 1, pp. 257-268, 2018, doi: 10.17576/JEM-20185201-21.

[2] T. Zulham, S. Hasyim, and J. Saputra, "Supply Chain Strategy for Convergence of Regional Economic Growth East Coast North Sumatera, Indonesia," Int. J. Supply Chain Manag., vol. 8, no. 5, pp. 325-336, 2019, Accessed: Mar. 02, 2021. [Online]. Available:

https://www.researchgate.net/publication/341 079877.

[3] T. Zulham, I. Hasan, J. Saputra, H. Noviar, and O. R. Risma, "Does the World Price of
Crude Palm Oil and Total of Production Determine Palm Oil Marketing Margins in Indonesia?," Ind. Eng. Manag. Syst., vol. 19, no. 3, pp. 520-526, 2020, Accessed: Mar. 02, 2021. [Online]. Available: https://www.dbpia.co.kr/Journal/articleDetail ?nodeId=NODE10443286.

[4] H. Noviar et al., "The Agricultural Commercialisation and its Impact on Economy Management: An Application of Duality-Neoclassic and Stochastic Frontier Approach," Ind. Eng. Manag. Syst., vol. 19, no. 3, pp. 510-519, 2020, doi: 10.7232/iems.2020.19.3.510.

[5] S. Syahril et al., "The effect of global prices of crude palm oil, marketing margins and palm oil plantations on the environmental destruction: An application of Johansen cointegration approach. ," Int. J. Energy Econ. Policy, vol. 9, no. 4, p. 305, 2019, doi: $10.32479 /$ ijeep.8010.

[6] K. Xu, J. Wang, J. Wang, X. Wang, ... Y. C.-J. of environmental, and undefined 2020, "Environmental function zoning for spatially differentiated environmental policies in China," Elsevier.

[7] E. Kulińska, M. D.-T. R. Procedia, and undefined 2019, "Green cities-problems and solutions in Turkey," Elsevier.

[8] A. B.-R. économique and undefined 1971, "Solow (RM)-Growth Theory, an Exposition.," persee.fr.

[9] "Book Review of" Encyclopedia of Applied Ethics " - Google Cendekia.".

[10] P. des N. U. pour l'environnement, "Sudan: post-conflict environmental assessment," 2007.

[11] G. Ma et al., "The valuation of China's environmental degradation from 2004 to 2017," Elsevier.

[12] A. K. Jorgenson, B. Clark, and J. Kentor, "Militarization and the Environment Militarization and the Environment: A Panel Study of Carbon Dioxide Emissions and the Ecological Footprints of Nations, 1970-2000 •," 2010.

[13] S. Sarkodie, S. Adams, P. Owusu, ... T. L.S. of the T., and undefined 2020, "Mitigating degradation and emissions in China: the role of environmental sustainability, human capital and renewable energy," Elsevier.

[14] I. Olanipekun, ... G. O.-W.-S. of the T., and undefined 2019, "Agriculture and environmental degradation in Africa: The 
role of income," Elsevier.

[15] S. Sukono et al., "The effect of gross domestic product and population growth on $\mathrm{CO} 2$ emissions in Indonesia: An application of the ant colony optimisation algorithm and cobb-douglas model.," Int. J. Energy Econ. Policy, vol. 9, no. 4, p. 313, 2019, doi: 10.32479/ijeep.8011.

[16] S. Sukono, J. Saputra, B. Subartin, H. Napitupulu, and Y. Hidayat, "Forecasting Model of Gross Regional Domestic Product (GRDP) Using Backpropagation of Levenberg-Marguardt Method," Ind. Eng. Manag. Syst., vol. 18, no. 3, pp. 530-540, 2019, doi: 10.7232/iems.2019.18.3.530.

[17] S. Sukono, J. Saputra, B. Subartini, J. Hotmaida Fransiska Purba, S. Supian, and Y. Hidayat, "An Application of Genetic Algorithm Approach and Cobb-Douglas Model for Predicting the Gross Regional Domestic Product by Expenditure-Based in Indonesia," Eng. Lett., vol. 27, no. 3, 2019, Accessed: Mar. 02, 2021. [Online]. Available:

http://www.engineeringletters.com/issues_v2 7/issue_3/EL_27_3_03.pdf.

[18] K. Warner, M. Hamza, A. Oliver-Smith, F. Renaud, A. J.-N. Hazards, and undefined 2010, "Climate change, environmental degradation and migration," Springer.

[19] D. Stern, M. Common, E. B.-W. development, and undefined 1996, "Economic growth and environmental degradation: the environmental Kuznets curve and sustainable development," Elsevier.

[20] T. T.-P. engineering and undefined 2012, "Urban flood disaster management," Elsevier.

[21] G. O'brien, P. O'keefe, J. Rose, and B. Wisner, "Climate change and disaster management." doi: 10.1111/J.14679523.2006.00307.X.

[22] D. Coppola, "Introduction to international disaster management," 2019.

[23] M. Dilley, "Natural disaster hotspots: a global risk analysis," 2005.

[24] O. L. Phillips et al., "Drought Sensitivity of the Amazon Rainforest," Springer, doi: 10.1126/science.1164033ï.

[25] M. Kennish, "Encyclopedia of Estuaries (Encyclopedia of Earth Sciences Series).," 2016.

[26] A. Safari, M. D.- Energy, and undefined 2018, "Oil price forecasting using a hybrid model," Elsevier.

[27] E. B. Barbier, "Poverty, development, and environment," Environ. Dev. Econ., vol. 15, pp. 635-660, 2010, doi: 10.1017/S1355770X1000032X.

[28] O. Peter, C. M.-P. Manufacturing, and undefined 2019, "Industrial energy conservation initiative and prospect for sustainable manufacturing," Elsevier.

[29] V. Costantini and S. Monni, "Environment, Human Development and Economic Growth," 2006.

[30] “35. Todaro, M., \& Smith, S. C. (2011). Chapter 5:... - Google Cendekia." .

[31] A. De Sherbinin, D. Carr, S. Cassels, and L. Jiang, "Population and environment," Аnnи. Rev. Environ. Resour., vol. 32, pp. 345-373, 2007 , doi: 10.1146/annurev.energy.32.041306.100243.

[32] B. B.-C. O. in E. Sustainability and undefined 2018, "Environmental indicators and governance," Elsevier.

[33] R. Benintendi, E. Gòmez, G. De Mare, A. N.-S. Futures, and undefined 2020, "Energy, environment and sustainable development of the belt and road initiative: The Chinese scenario and Western contributions," Elsevier.

[34] R. H. Wade, "Is globalization reducing poverty and inequality?," International Journal of Health Services, vol. 34, no. 3. pp. 381-414, 2004, doi: 10.2190/G8F101FL-MEDW-JVG1.

[35] G. O'Brien, P. O'Keefe, J. Rose, and B. Wisner, "Climate change and disaster management," Disasters, vol. 30, no. 1, pp. 64-80, Mar. 2006, doi: 10.1111/j.14679523.2006.00307.x.

[36] J. J. Ferreira, A. Fayolle, C. Fernandes, and M. Raposo, "Effects of Schumpeterian and Kirznerian entrepreneurship on economic growth: panel data evidence," Entrep. Reg. Dev., vol. 29, no. 1-2, pp. 27-50, Jan. 2017, doi: $10.1080 / 08985626.2016 .1255431$.

[37] H. Kan, R. Chen, S. T.-E. international, and undefined 2012, "Ambient air pollution, climate change, and population health in China," Elsevier.

[38] D. W. Cheek, "A Panoramic View of the Future of Learning and the Role of Design(ers) in Such Experiences," in The Design of Learning Experience, Springer International Publishing, 2015, pp. 5-37.

[39] Central Bureau of Statistics Indonesia, "Indonesia Statistic 2018," 2018. 
https:/www.google.com/search?q=Central+ Bureau + of + Statistics+Indonesia $+(2018) \& o q$ $=$ Central + Bureau + of + Statistics + Indonesia +( 2018)\&aqs=chrome..69i57j69i60.904j0j7\&s ourceid $=$ chrome\&ie $=$ UTF- 8 (accessed Feb. 23, 2021).

[40] "Dasar-dasar ekonometrika Edisi 5 Buku 1. Jakarta:... - Google Cendekia." .

[41] A. Aloisio, R. Alaggio, M. F.-E. Structures, and undefined 2019, "Dynamic identification of a masonry façade from seismic response data based on an elementary ordinary least squares approach," Elsevier.

[42] K. I.-T. S. Review and undefined 2010, "The impact of oil price hike on the Belarusian economy," Springer.

[43] B. Yuan, Y. Z.-J. of C. Production, and undefined 2020, "Flexible environmental policy, technological innovation and sustainable development of China's industry: The moderating effect of environment regulatory," Elsevier.

[44] A. Sherbinin, D. Carr, ... S. C.-A. R. E., and undefined 2007, "Population and environment," annualreviews.org.

\section{Contribution of individual authors to the creation of a scientific article (ghostwriting policy)}

T. Zulham writing - original draft, investigation and supervision

Taufiq C. Dawood writing - original draft, investigation, editing and supervision.

Talbani Farlian writing - original draft, investigation, editing and data analysis.

Jumadil Saputra writing - methodology, review, editing, investigation, and data analysis.

Rollis Juliansyah writing - methodology, review, and editing.

Fajri Hadi writing - methodology, review, and editing.

\section{Sources of funding for research presented in a scientific article or scientific article itself \\ Report potential sources of funding if there is any}

\section{Creative Commons Attribution \\ License 4.0 (Attribution 4.0 \\ International, CC BY 4.0)}

This article is published under the terms of the Creative Commons Attribution License 4.0

https://creativecommons.org/licenses/by/4.0/deed.en US 